\title{
THOMAS MANN: UM ESCRITOR CONTRA O NAZISMO ${ }^{1}$
}

\author{
Sonia DAYAN-HERZBRUN ${ }^{2}$
}

- RESUMO: O combate que Thomas Mann travou contra o nazismo a partir de 1922 é exemplar, pois é o de um escritor apaixonado pela liberdade e não o de um militante. Ele privilegia a ficção e o mito como meios de luta contra o fascínio exercido pelo nazismo e afirma a permanência de uma Alemanha cultural, cosmopolita, fonte de uma universalidade estranha a todos os particularismos étnicos. Goethe, com quem ele se identifica e no qual se projeta, é a figura de proa dessa Alemanha.

- PALAVRAS-CHAVE: República de Weimar; nazismo; cosmopolitismo; literatura alemã.

A sociologia não pode deixar de se interrogar sobre o lugar do escritor no espaço político. Habermas mostrou recentemente o papel da esfera pública literária na constituição do espaço público nos séculos XVII e XVIII. A esfera pública política é, diz ele, "originária de sua forma literária, e as opiniões públicas que dela emanam representam um papel de mediador entre as necessidades da sociedade e o Estado" (Habermas, 1978, p.41). Podemos considerar que a dissidência dos países do Leste europeu enquadra-se no mesmo tipo de análise. A posição dos escritores de língua alemã que tomaram partido publicamente contra o nazismo, e aos quais Albrecht Betz (1991) dedicou recentemente um belo livro, ${ }^{3}$ é mais complexa. Primeiro em razão de suas origens múltiplas, de sua

1 Tradução de Nelson Luís Ramos - Departamento de Letras Modernas - Instituto de Biociências, Letras e Ciências Exatas - UNESP - 15054-000 - São José do Rio Preto - SP - Brasil.

2 Universidade de Paris VII - Denis Diderot.

3 Cf. também Jean-Michel Palmier, Weimar en exil, Paris, 1990. 
diversidade ideológica e de sua situação de exilados. Aqueles que pertenciam a um movimento já constituído (o sionismo de Hannah Arendt, o comunismo de Brecht ou Anna Seghers) puderam agir e tomar a palavra a partir dessas formações, que proporcionavam um quadro intelectual e político às suas ações. As dificuldades que encontraram e que não saberíamos avaliar estão relacionadas com os problemas e os conflitos próprios desses movimentos. Eles estavam, entretanto, inseridos em um espaço comum que fazia sentido de imediato para eles e para os outros. Ao término da guerra, por exemplo, os escritores comunistas alemães voltaram com o fim de se estabelecer na Alemanha Oriental. Sua presença era útil ao regime que então se instalava, pois ele encontrava nesses resistentes do primeiro momento uma legitimação que lhe permitia, por outro lado, fazer a economia da real desnazificação que teria implicado igualmente um ataque ao totalitarismo.

Para os outros, a fuga do país de origem tomou muitas vezes a forma de um nomadismo sem fim, levando freqüentemente ao desespero e ao suicídio. Tratados como inimigos por seus compatriotas, eles também eram recebidos como inimigos pelos países nos quais buscavam refúgio. A identificação dos valores nacionais com o nazismo impediu o desenvolvimento de uma resistência interna, liberal ou democrática, na qual esses exilados teriam podido se apoiar. Podemos então nos perguntar a partir de que ponto, supostamente fixo, opera-se a reconstrução de um espaço de expressão e de liberdade que alguns, no entanto, empreendem.

\section{Um romancista na política}

Desse ponto de vista, o combate de Thomas Mann é exemplar. Ele entra na arena política em 1922 tomando posição publicamente em prol da nova e frágil República de Weimar ${ }^{4}$ e, portanto, da democracia. Entretanto, não é como militante, mas como escritor, que ele lança seu grito de Viva a República por meio do qual proclama sua ruptura com as idéias que desenvolvera nas suas Meditações de um apolitico, sobre as quais será necessário retornar longamente. Escritor, porque ele escolhe um acontecimento literário para fazer esta declaração solene: a celebração na Beethovensaal de Berlim do sexagésimo aniversário de seu amigo Gerhart Hauptmann, também escritor, que serviu de modelo ao Mynheer Pe-

4 Cf. "De la République allemande”, em Mann, 1976, p.19-57. 
perkorn de $A$ montanha mágica. Escritor porque sua reflexão só se refere a filósofos ou poetas, nunca a políticos. Sua proposta é, de fato, mostrar que pode haver uma leitura humanista e democrática do romantismo alemão, ${ }^{5}$ contrariamente ao que ele mesmo afirmava até há pouco, e que os partidários do isolamento estético ou de "um indigno naufrágio do indivíduo" ainda defendiam. Reconhecemos aqui as posições social-democratas (no sentido pleno e não reduzido do termo) que serão, a partir desse momento, as de Thomas Mann até o fim de seus dias. Finalmente - e aí se encontra, sem dúvida, o ponto mais original -, é a partir do interior de sua própria obra, e no momento em que esta parece mais próxima da ficção, que Thomas Mann se torna sensível ao aspecto político, e o torna sensível a quem sabe e quer lê-lo. Em uma carta a Arthur Schnitzler, ele atribui a evolução testemunhada por seu ensaio De la République allemande [Da República alemã] ao trabalho de elaboração de $A$ montanha mágica que será publicado em 1924 e contribuirá para a sua obtenção do Prêmio Nobel em 1929. "Exorto a fração recalcitrante de nossa juventude e de nossa burguesia a se colocar finalmente sem posicionamento prévio ao serviço da República e da humanidade - uma tendência que talvez lhes causará espanto ... E quanto ao amor pelo pensamento da humanidade que eu constato depois de algum tempo em mim, ele se encontra talvez em conexão com o romance no qual traballho já há muito tempo, uma espécie de romance educativo e de 'Wilhelm Meisteriade' em que a experiência da enfermidade e da morte leva um rapaz a conceber a idéia do homem e do Estado." Thomas Mann se viu aqui, ao mesmo tempo, como um segundo Goethe, que escreve um novo $\mathrm{Wi}$ lhelm Meister, e como uma cópia de Hans Castorp, o herói de A montanha mágica. Obcecado por Goethe ao longo de toda a sua existência, Thomas Mann resolve o problema dessa dupla identificação com os diferentes heróis de suas obras e com o mestre da literatura alemã quando faz do próprio Goethe o herói daquele que será seu romance preferido, e seu manifesto antinazista mais radical, na sua Lotte em Weimar, terminado nos Estados Unidos em 1940.

5 "Novalis ... declara: 'O direito dos povos marca o início da legislação universal, do Estado universal.' E ele exprime em tempo necessário o que hoje todos os pardais cantam nos telhados: Os Estados devem finalmente se dar conta de que a realização de todos os seus objetivos só é possível por meio de medidas gerais. Nada pode ser feito: tudo isso é do domínio da Aufklärung política, faz parte incontestavelmente da democracia - na boca de um cavaleiro da flor azul, que foi, além disso, um nobre de nascença, e de quem poderíamos esperar, ao invés dessas idéias modernas, um senso do combate medieval e da dignidade em grande acompanhamento" ("De la République allemande", op. cit., p.48-9)

6 Carta a Arthur Schnitzler de 4 de novembro de 1922 (Mann, 1966, p.248). 
Além de sua correspondência e de seu diário, Thomas Mann deixa outros dois tipos de obras literárias: de um lado ensaios e conferências, feitas durante a guerra sob a forma de programas de rádio $-^{7}$ o que ele chamava suas tarefas do dia e às quais se consagrava à tarde -, e de outro romances ou novelas nos quais trabalha pela manhã, com o máximo de sua lucidez, e nos quais, tal como se vê na leitura de sua correspondência, seu investimento pessoal e político é mais forte.

Entretanto, esses últimos textos, de escrita apurada e trabalhada, não parecem muito obras "de tese". Podemos fazer uma leitura puramente estética delas, já que o "engajamento" parece aí encontrar pouco espaço. Pelo contrário: o imaginário, o mito, as referências culturais nela abundam. Na linha estrita do que ele próprio define como a tradição alemã, a razão política toma emprestado, efetivamente, em Thomas Mann, o desvio da afetividade, do imaginário, e até mesmo do simbólico, mas é para melhor alimentar a escrita romanesca. Doutor Fausto, publicado em 1949, no momento em que se impõe para o autor a questão do retorno, é assim uma última resposta à questão que não deixa de perseguir Thomas Mann: o que é ser alemão? A tetralogia José e seus irmãos, publicada entre 1933 e 1943, desenvolve os temas do exílio e da vida errante, e refere-se a uma certa proximidade entre os povos judeus e alemães que Thomas Mann afirma no auge das perseguições. Contra o arianismo nazista, Thomas Mann reitera, também por meio desta obra, uma de suas idéias fortes, que é a da origem oriental, mediterrânea e judia da Europa. Este tema também está presente em Lotte em Weimar, em que Goethe torna-se porta-voz da Alemanha antinazista, a tal ponto que o texto é citado - por um erro - no tribunal de Nuremberg. Thomas Mann diverte-se com isso. ${ }^{8}$ Ainda

7 De outubro de 1940 a maio de 1945, Thomas Mann gravou, na Califórnia, onde morava, um programa mensal emitido pela BBC. Alemão, ele queria falar em alemão aos alemães. Martin Flinker, que publicou esses textos, compara esses apelos aos do General de Gaulle. Thomas Mann queria de todas as formas que seus ouvintes escutassem o próprio som de sua voz, originando daí uma montagem técnica complicada que ele próprio inventara: "No Recording Department da NBC em Los Angeles eu mesmo gravo em um disco o que tenho para dizer; este disco é enviado por via aérea a Nova Iorque e seu conteúdo é retransmitido por telefone para Londres para um outro disco que roda diante do microfone. Dessa forma, aqueles que, do outro lado, ousam ficar à escuta, ouvem não somente a minha mensagem, mas a minha própria voz" (Mann, 1984, p.44).

8 "Causei uma grande e engraçada confusão. Talvez você tenha ficado sabendo da história? O prosecutor britânico de Nuremberg, acreditando citar um autêntico termo de Goethe sobre os alemães, na realidade o teria tomado emprestado de Lotte em Weimar. A vigilante imprensa inglesa lançou altos brados, clamando que não era de forma alguma de Goethe, mas retirado de meu romance, e a embaixada em Washington, muito embaraçada, mandou-me perguntar qual era a verdade. Respondi que eu garantia que Goethe teria muito bem podido pensar e dizer tudo o que ele pensa e diz no meu romance, e, dessa forma, num sentido mais amplo, a citação do prosecutor 
aqui a ficção foi mais real do que o que se toma por um fato. Essa anedota confirma o que Mann declarava já em 1930: "A realidade espiritual também é uma realidade, talvez até uma realidade primária .... O romancista não molda a vida unicamente em sua obra, mas muitas vezes também por meio de sua obra. ${ }^{9} "$

Diferentemente de seu irmão Heinrich, Thomas Mann não quer ser militante, mas artista. É como artista que ele paira "acima do conflito"10 durante a Primeira Guerra Mundial; é como artista - e, mais especificamente, como escritor alemão - que ele entra na guerra, em outubro de $1940 .{ }^{11}$ Ele luta em seu próprio nome, e principalmente por essa obra que não se distingue dele mesmo. ${ }^{12}$ Quando uma esquadrilha da aviação britânica bombardeia a casa de seus avós em Lübeck, ele anuncia no rádio, em um programa especial, a destruição da casa dos Buddenbroock, símbolo, diz, da tradição que o fazia agir (cf. Mann, 1984, p.146). Ao longo de toda a sua existência Thomas Mann se apresenta como um "conservador", cuja "tarefa natural nesse mundo consiste em preservar". ${ }^{13}$ Esse conservadorismo, sobre o qual devemos nos perguntar o que se esforça em conservar, marca as escolhas sucessivas do escritor.

\section{Do apolítico ao engajado}

No belo estudo que consagra às Meditações de um apolítico, Louis Dumont (1991, p.75-89) assinala que esse livro, nunca renegado por seu autor, constitui um aporte fundamental para a compreensão do "papel representativo ou mediador do grande escritor ou artista característico da Alemanha" (Dumont, 1991, p.89). Sabemos que essa grande obra, que,

estava correta" (carta a Victor Mann, de 4 de outubro de 1946).

9 “A situação espiritual do escritor em nossa época" (Mann, 1976, p.87)

10 Cf. Mann, 1975, p.19.

11 Seu primeiro programa começa, de fato, com estas palavras: "Ouvintes alemães! Um escritor alemão lhes fala, cuja obra e pessoa foram banidos por seus mestres, e cujos livros, mesmo quando tratam do que há de mais alemão - de Goethe, por exemplo -, só podem se dirigir em sua língua original a povos estrangeiros, a povos livres, enquanto eles devem, forçadamente, permanecer para vocês como letra morta, e ignorados. Minha obra voltará um dia para vocês, eu sei, quando eu próprio não poderei mais fazê-lo" (Mann, 1984, p.49).

12 "Eu faço a guerra e vocês gostariam de me ver acima do conflito, por indulgência. Ora, esse conflito é uma batalha decisiva da humanidade; ele decidirá tudo, até o destino da minha obra, que durante dezenas de anos, pelo menos, não terá mais o direito de voltar à Alemanha, de se inserir na ordem de sua tradição, caso triunfasse a miserável raça de animais para a qual um mundo indolente, covarde, ignorante só preparou vitórias durante oito anos" (carta a Agnès E. Meyer, de 24 de janeiro de 1941).

13 Cf. "De la République allemande", em Mann, 1976, p.36. 
segundo o próprio autor, está mais para um poema do que para um ensaio, foi escrita durante a Primeira Guerra, em protesto contra o pacifismo internacionalista proclamado por seu irmão mais velho, também romancista, Heinrich Mann. No entanto, não se trata, de forma alguma, de um manifesto belicista, mas de uma longa meditação sobre a relação que a cultura alemã mantém com a política. Alemã, porque Thomas Mann, diferentemente de seu irmão, recusa a tese universalista: tanto o universalismo como o humanitarismo não são senão fraseologia mentirosa, debatida pelas potências imperialistas que são a França e a Inglaterra, que não hesitaram em empregar a tortura no momento da conquista da África e que negam aos alemães a qualidade de seres humanos. ${ }^{14}$ Aquele que se diz pacifista e internacionalista é, inicialmente, antialemão, não em virtude do campo no qual se situa, mas porque ele invoca valores que são os dos inimigos da Alemanha.

Esse processo repousa na oposição, tornada clássica a partir dos trabalhos de Elias, entre cultura e civilização. ${ }^{15}$ Nos seus escritos autobiográficos, Elias (1991, p.129-130) reconhece o que sua reflexão nessa matéria deve à leitura de Thomas Mann. Essa oposição remete àquela de duas formas do sentimento nacional, e, portanto, de duas concepções de nação: concepção política, ligada ao âmbito da civilização, concepção cultural, presa a outro, em que a idéia de povo prevalece sobre a de nação. $\mathrm{O}$ internacionalismo que os pacifistas invocam pressupõe a existência de nações políticas, com contornos territoriais nitidamente definidos, e que não é, portanto, compatível com a nação cultural alemã que se alia, por sua vez, ao cosmopolitismo.

A política se desdobra no espaço aberto e organizado pelo discurso. Ora, a cultura, de cuja tradição Thomas Mann é o intérprete, não mantém nenhuma relação privilegiada com a discursividade. A França e a Inglaterra, herdeiras de Roma, têm o verbo generoso. A Alemanha, por

14 "Nas colunas do Temps foi elogiada recentemente uma obra em que o autor, um sábio notório, Bérillon, professor de psiquiatria, demonstra que os alemães não são seres humanos, mas que pertencem antes a uma espécie inferior, resultante indubitavelmente da forma de seus órgãos sensoriais, de seu abdômen, de seu odor, bem como da conformação de suas secreções animais" (Mann, 1975, p.378).

15 “A noção de civilização elimina, até certo ponto, as diferenças entre os povos; ela insiste, na sensibilidade dos que dela se servem, no que é comum a todos os homens ou, pelo menos, deveria sê-lo. Ela exprime a auto-satisfação dos povos cujas fronteiras nacionais e caracteres específicos não são mais, há séculos, questionados, porque eles já se fixaram definitivamente, povos que já há muito tempo ultrapassaram suas fronteiras e se lançaram em atividades colonizadoras. A noção alemã de 'cultura', ao contrário, assinala as diferenças nacionais, as particularidades dos grupos etc." (Elias, 1989, p.13-4) 
muito tempo privada da palavra, é, ao contrário, um "país não-literário" (Mann, 1975, p.50). O apolitismo também é "a-literatura". A cultura alemã é, essencialmente, poesia e música. A filosofia vem bem depois. "O próprio romance não é um gênero realmente alemão" (p.68). O romance de formação (Bildungsroman) que, concedendo um espaço maior à introspecção, caminha nas profundezas da interioridade, como o Wilhelm Meister de Goethe, verdadeira obra-guia, resulta de uma salutar - é verdade - europeização. Mas o romance de costumes, à Zola, pertence inteiramente ao mundo da civilização e, portanto, da política. A própria forma das obras produzidas no interior da cultura germânica parece mantê-las longe de um investimento político qualquer. A evolução de Thomas Mann o levará a dar um sentido político ao Bildungsroman ao qual ele permanecerá ligado.

Esse apolitismo da obra de arte é reforçado pelo apolitismo do artista. Na tradição cultural alemã, o artista é, com efeito, um burguês, quer dizer, um "homem do meio", colocado entre dois mundos, mantido entre o povo e uma aristocracia fechada em cujas fileiras nunca será admitido (p.101). Burguês, ele desenvolve as virtudes burguesas e, em princípio, a primazia da ética na vida. "O estado do artista é burguês no que ele transpõe, no exercício da arte, as características morais da vida burguesa: ordem, conseqüência, calma, zelo - não no sentido de uma aplicação laboriosa, mas da fidelidade artesanal" (p.96). ${ }^{16}$ Excluídos das decisões dos príncipes, esses artistas burgueses e individualistas, dos quais Goethe é o representante mais eminente, longe de se unirem em um impulso democrático e revolucionário, vão se desviar da política e até abominá-la. ${ }^{17}$ E é aí que encontram o povo, cuja alma se exprime nos indivíduos e não nos problemas técnicos do Estado, ${ }^{18}$ pois "a política é um interesse orientado para o Estado, é o zelo e a paixão que o Estado inspira", ${ }^{19} \mathrm{em}$ que não se realiza nenhuma vocação verdadeiramente humana e que só tem a ver com entidades abstratas e não com o real vivido: "O incêndio de uma fazenda, dizia Goethe, é uma verdadeira infelicidade, uma catástrofe, enquanto a 'ruína da pátria' é apenas uma frase". ${ }^{20}$ Daí a decisão de deixar

16 Thomas Mann tem perfeita consciência das concordâncias entre suas análises e as de Troeltsch e de Max Weber, de quem, no entanto, não sofreu influência.

17 "Em que medida Goethe imprimiu na mentalidade burguesa alemã esse caráter de vida interior, de cultura humanista, esse horror à política, e em que medida essa mesma mentalidade já era, na sua pessoa, um produto do espírito burguês tipicamente alemão, é difícil dizê-lo" ("Goethe représentant de l'âge bourgeois", em Mann, 1960, p.26-7).

18 Mann, 1975, p.135.

19 Cf. Mann, 1975, p.133. 
a gestão dos negócios públicos para os que são do ramo. O antidemocratismo que Thomas Mann desenvolve após Goethe, Schopenhauer ou Nietzsche é apenas a conseqüência dessa indiferença política. Nas Meditações, ele define, de fato, a democracia como a politização da ética, limitada a um quadro estatal e nacional. A idéia democrática repousa num desconhecimento do povo, cuja natureza não o conduz nem em direção às luzes, nem ao progresso, nem à paz, nem à justiça. As instituições políticas têm o papel de canalizar o povo, "um ser ao mesmo tempo incapaz de governar e de se deixar governar". Thomas Mann se reapropria da crítica clássica da democracia/demagogia, para acrescentar que a forma política adequada ao povo alemão é a do Estado autoritário, que dispensa o artista das tarefas fastidiosas de gestão da vida coletiva e deixa cada indivíduo livre para suas escolhas éticas, estéticas e culturais.

Pois a cultura alemã se dissocia do político: ela se desenvolve não somente em outros estados, mas é realmente de essência cosmopolita. Esse núcleo estritamente alemão não pode se desenvolver senão graças a aportes múltiplos. O burguês alemão, dizíamos, é "homem do meio", e com duplo sentido, porque a Alemanha está situada no meio da Europa, numa posição mediana e mediadora que a deixa aberta a todas as influências. Paradoxalmente (e Thomas Mann, de ascendência meio-germânica, meio-latina da América do Sul, casado, além do mais, com uma mulher meio-judia, apresenta-se como uma ilustração viva do paradoxo): "É quase inerente ao alemão mostrar-se não-alemão e até antialemão; uma tendência ao cosmopolitismo que desagrega o senso nacional é ... inseparável da natureza alemã; é necessário, talvez, perder seu germanismo para poder encontrá-lo; sem uma contribuição estrangeira, talvez nenhum germanismo superior seja possível; os alemães superiores, precisamente, foram europeus e acharam bárbaro confinar-se estritamente apenas no seu germanismo" (Mann, 1975, p.68-9).

Após a guerra, entregando-se a uma autocrítica afetuosa, Thomas Mann reconhecerá que foi seu irmão Heinrich que tivera razão pregando a democracia, enquanto ele próprio "se comprazia na defesa melancólica de uma burguesia intelectual protestante, romântica e antipolítica". ${ }^{21}$ Sua "passagem forçada à política"22 é acompanhada de uma redefinição da democracia, que se torna a condição do exercício da liberdade individual,

20 “Goethe représentant de l'âge bourgeois", em Mann, 1960, p.25.

21 Carta à redação do Freies Deutschland, de 6 de fevereiro de 1946. O apolitismo estetizante e guerreiro de seu velho amigo Ernst Jünger não foi, sem dúvida, estranho a esta condenação (cf. Dayan-Herzbrun, 1993) 
reconhecendo "na política e no social uma parte da totalidade humana" (Mann, 1979, p.226). São, no entanto, os mesmos princípios fundamentais que o levaram a redigir as Meditações de um apolítico que o convencem a se engajar na defesa da República de Weimar e, depois, na luta contra o fascismo e o nazismo, ${ }^{23}$ ou seja, a primazia da ética individual, a defesa da liberdade e o amor por uma Alemanha cosmopolita, européia, pátria dos sem-pátria e de um "povo universal" (Mann, 1975, p.209). Quanto mais os anos passarão, mais ele virá a duvidar da existência dessa Alemanha, distante de seus desejos e de seus sonhos.

\section{Fascismo e liberdade}

A ascensão do nazismo suscita em Thomas Mann uma torrente de emoções da qual ele não se livrará: dor, desgosto, espanto e, principalmente, ódio, ardente paixão que o levará a duvidar de seus compatriotas. ${ }^{24}$ Lúcido, zeloso, ele deixa, às vezes, explodir sua cólera no seu diário ou nos seus programas na $\mathrm{BBC} .{ }^{25}$ Mas ele toma cuidado para não se deixar submergir por seus afetos e, principalmente, para não ceder ao fascínio dos acontecimentos. Pois o fascismo, o nazismo, bem como as personagens que a eles estão ligadas, e Hitler sobretudo, causam fascinação. Thomas Mann consagra poucos textos à sua análise, mas dois dentre eles têm uma importância maior: Mário e o mágico, uma longa novela escrita em 1929, e um curtíssimo ensaio, Frère Hitler, de 1938, sendo ambos histórias de fascinação. A novela termina num apelo à resistência: $\mathrm{Ci}$ polla, o hipnotizador - que mantém à sua mercê o público da pequena estação balneária italiana onde ele se apresenta, de uma Itália já partidária do fascismo - é finalmente arrasado por Mário, que o havia rebaixado e humilhado profundamente diante do público que assistia ao espetáculo. Mas a Europa impotente e humilhada não se comporta como Mário: ela

22 Tal era o título original do artigo de 1939, publicado posteriormente com o título de "Cultura e política", no qual Mann denuncia a ausência de vontade política no conceito cultural alemão, que abre caminho para um absolutismo do Estado sem liberdade moral nem cívica.

23 Cf. carta a Ida Boy-End, de 5 de dezembro de 1922.

24 "Consagrei aos infames destruidores da Alemanha e da Europa um ódio incondicional, mortal" (Mann, 1976, p.335)

25 Como se vê no programa de 14 de janeiro de 1945, consagrado à descoberta dos campos de extermínio, e que termina desta forma: "O horror, a vergonha e o arrependimento, eis o que é necessário, em primeiro lugar. E um único ódio se impõe: aquele que pesa sobre os bandidos que fizeram da palavra 'alemão' uma abominação diante de Deus e do mundo" (Mann, 1984, p.287). 
cede sem combater ao fascínio de Hitler, homem medíocre e que entrou na política "por falta de aptidão para outra profissão qualquer". ${ }^{26}$

É essa mesma mediocridade própria do nada que, em suma, não possui senão um instrumento vulgar, histérico e histriônico, "uma eloqüência indizivelmente inferior, mas arrastando as massas ..., que the permite remexer a faca na ferida do povo, emocioná-lo proclamando sua grandeza ofendida, iludi-lo com promessas etc". ${ }^{27} \mathrm{O}$ nazismo depende da magia e da hipnose, e as palavras que saem da boca dessa personagem específica, "o pequeno Adolfo", têm o poder de transformar a realidade. Os elementos da história de Hitler parecem retirados dos contos de fadas - e também da psicopatologia, que realizam no plano da imaginação os desejos escondidos de cada um, e nos quais o patinho feio revela-se um cisne. A lógica do nazismo é, compreende-se, a do processo primário do sonho, ${ }^{28}$ ou, para ser mais preciso, do pesadelo. Hitler é, de certa forma, a encarnação da inconsciência e do inconsciente da Alemanha, e é nesse sentido que ele é o irmão de cada alemão, que deve se reconhecer nele para melhor se afastar desse conceito. À sedução é necessário opor a liberdade, à magia das palavras resistir por outros termos capazes de produzir uma outra realidade. Pois "o mundo já foi transformado de outra forma que não pelo pensamento? e por seu suporte mágico: a palavra?" 29 Visando romper o fascínio que Hitler exerce sobre os alemães, Thomas Mann invoca "o grande destruidor de ilusões" de Viena, "seu inimigo verdadeiro e essencial, o filósofo que desmascarou a neurose ... aquele que sabe buscar a verdade das coisas e conhece muito sobre o gênio". ${ }^{30} \mathrm{O}$ trabalho psicanalítico é liberador, como o é toda obra verdadeiramente criadora. ${ }^{31}$

A literatura permite a Thomas Mann afirmar a liberdade, bem como a sua liberdade. Sua liberdade na medida em que, mediante as perseguições e o exílio, a despeito da proibição de que seus livros são objeto

31 Há uma proximidade evidente entre os grandes temas da obra de Thomas Mann (o que ele chama sua necessidade de verdade psicológica, e seu interesse pela doença como meio de atingir o conhecimento) e a abordagem psicanalítica, no sentido da ortodoxia freudiana. Só poderíamos aqui indicá-la, sem ter meios para detalhá-la
} 
em seu país natal e que o priva de uma grande parte de seus leitores, ele não se deixa aviltar e paralisar pelo ódio, mas continua a escrever obras serenas que dão forma a um outro mundo do qual o nazismo está excluído: um Oriente-Médio mítico com os José, uma Índia também mítica, em As cabeças trocadas, a cidade de Weimar em 1816, em Lotte. ${ }^{32}$ Podemos atacar sua pessoa ou os seus próximos, mas nada podemos fazer contra seus livros, que contêm o melhor dele mesmo. ${ }^{33}$ Destituído, com os seus, desde 1933, da nacionalidade alemã, forçado ao exílio e à adoção da nacionalidade americana, Thomas Mann não cede, permanecendo fiel à língua alemã, essa pátria autêntica que nenhum potentado pode arrancar; ele não somente persiste em escrever em alemão, mas trabalha, o máximo possível, todas as suas nuanças. ${ }^{34}$

Os temas desenvolvidos na obra romanesca dessa literatura de emigrante são manifestações de liberdade. Num artigo a ele consagrado, o polonês Adam Michnik qualifica Thomas Mann de "Dom Quixote alemão" ${ }^{35}$ A comparação pretende ser carinhosa, mas ela falha no seu objetivo. Thomas Mann combateu o "mal radical", e não o dos moinhos de vento. Ele utilizou, como outros, a arma da escrita para fazer compreender a excelência humana sobretudo onde não havia mais que aniquilamento.

O primeiro volume de José - As histórias de Jacó - é publicado em 1933, o ano da invasão definitiva dos camisas pardas, o ano do exílio forçado. ${ }^{36}$ Thomas Mann a ele se dedicara havia muito tempo. Em 1927, ele se dirigira a Jacob Horowitz, rabino em Frankfurt-sobre-o-Meno e autor de uma Histoire de Joseph (pela qual experimenta, escreve ele, "um inte-

32 Cf. a carta a Agnès E. Meyer, de 24 de janeiro de 1941.

33 "Em um de seus últimos discursos, o pequeno Adolf teria furiosamente desaprovado minha mensagem de Natal. O gauleiter Lindbergh vai certamente receber a ordem para me libertar. Mas José estará terminado antes, e então, de que servirá isso a Adolf?" (carta a Agnès E. Meyer, de 2 de maio de 1941). Para entender todos os termos desta passagem, é necessário recordar-se que o aviador Charles Lindbergh, que não escondia suas simpatias pró-nazistas, era então uma das figuras de proa dos não-intervencionistas americanos, hostis à entrada dos Estados Unidos na guerra ao lado dos Aliados.

34 "Contrariamente, no exterior ... meu trabalho, precisamente durante aqueles anos, tornou-se cada vez mais uma obra lingüística consciente, o prazer de trabalhar com todos os registros do magnífico sistema organístico do nosso idioma, de tentar um esforço de recapitulação e ao mesmo tempo fazer progredir o estado do alemão e as possibilidades de expressão da prosa alemã" ("Allocution en l'année Goethe", em Mann, 1976, p.335).

35 "Existiu um Dom Quixote alemão, um escritor impotente que, esmagado pelo desgosto, desejou a derrota dos carrascos nazistas etc." (Michnik, 1990, p.154).

36 Sobre as circunstâncias desse exílio, ver Klaus Mann, Le tournant, cap. IX. 
resse particular, ardente"), a fim de se aconselhar e confrontar suas interpretações da história bíblica. Por que se arriscar, sem uma razão firme, durante mais de quinze anos, em um terreno "tão estranho, distante, escabroso, por alguém que sempre foi acostumado a se mover no plano burguês"? ? ${ }^{37} \mathrm{O}$ tom e os termos da carta ao rabino Horowitz dão bem o tom que Thomas Mann quer que seja a expressão e a alternância de uma tradição sobre a qual sente pesar fortes ameaças. Sua tetralogia consagrada aos patriarcas deve ser lida como uma resposta às perseguições anti-semitas e, depois, ao genocídio, tanto mais que aí se encontra expressa a origem oriental, mediterrânea e judia da Europa. Europeus, os judeus são particularmente próximos dos alemães, por sua vida errante e por seu cosmopolitismo.

\section{Alemanha e cosmopolitismo}

"A noção de 'alemão' é um abismo sem fundo", constatava Mann (1975, p.56) nas Meditações e ele não cessará de questioná-la. O germanismo envolve uma tensão entre nacionalismo (não-político, lembremonos) e cosmopolitismo que não pode ser resolvida senão em benefício do cosmopolitismo, a partir do momento em que o nacionalismo toma o aspecto do etnicismo político e racial. O nazismo tentou se apropriar da cultura alemã, reinterpretando-a num sentido étnico-nacional. Thomas Mann, consciente da ambigüidade política do romantismo, contesta vigorosamente esta apropriação, como se vê nos estudos que consagra a Nietzsche, a Wagner, ${ }^{38}$ a Schopenhauer etc. Mas é de Goethe, antes de mais nada, que ele vai fazer seu porta-voz, em um duplo movimento de identificação e de substituição. Apoiando-se no entusiasmo, no humanismo e no amor pela vida do velho poeta do Segundo Fausto, ele não hesita em apresentá-lo como um precursor do socialismo e da democracia. ${ }^{39}$

37 Carta a Jacob Horowitz, de 11 de junho de 1927.

38 "O espírito alemão era tudo para ele, o Estado alemão absolutamente nada, como já nos revela esta frase de onde saíram Os mestres cantores: 'Se o Santo Império romano fosse disperso pelos quatro ventos, sempre nos restaria nossa santa arte alemã ... Sua verdadeira mensagem ... é a melodia celeste"” ("Richard Wagner et l'Anneau du Nibelung", em Mann, 1960, p.183. Essa conferência foi pronunciada em 1937)

39 "A alegria que sentia pelo futuro era de larga envergadura; ele precisava do espaço, do mundo inteiro ... No racionalismo de semelhantes utopias técnicas, o espírito burguês se eleva até o sentimento da comunidade universal e - se quisermos tomar o vocábulo em um sentido bastante geral e esvaziá-lo de todo conteúdo doutrinário - até o comunismo" "“Goethe représentant de l'âge bourgeois"(1932), em Mann, 1960, p.44). Em 1949 ele reconhece, mas sem se retratar: "Eu sei que é preciso ir até o fundo das coisas e dar uma acepção muito ampla ao conceito de democracia para aí incluir Goethe" ("Goethe und die Demokratie", em Mann, 1982, p.290). 
Goethe, porém, vai ser seu aliado principalmente no combate contra o nazismo. Ele vai invocá-lo para denunciar o particularismo étnico e racial, bem como o anti-semitismo, e sustentar, sem parar, que ambos são estranhos à espiritualidade germânica. Lotte em Weimar, que aparece em 1940, dá vida e cor às idéias mais abstratas desenvolvidas nos ensaios. Esse romance, que é a realização de um mito - como escreve Thomas Mann ao seu irmão Heinrich - porque introduz o leitor na intimidade de Goethe, também lhe é o mais querido. ${ }^{40}$ É uma história de amor, para começar, uma história de amor e do tempo que passa. Lotte Kestner, aquela que foi amada por Goethe 44 anos antes sob o nome de Charlotte Buff e que lhe inspirou a personagem da heroína de Werther, ficando viúva, decide, em 1816, fazer uma visita, em Weimar, ao objeto do seu amor de juventude. A bela jovem tornou-se uma velha senhora cheia de ternura e de espírito, curiosa para saber como se encontra agora aquele que tanto a amou. Claro, o amor não renascerá entre Charlotte e um Goethe que tem quase a idade do autor do romance, mas num jantar que os reunirá - e ao longo do qual eles não deixarão de se observar - Goethe confiará algumas de suas reflexões mais profundas sobre o seu próprio destino e sobre o da Alemanha. Inspiradas pelo conhecimento íntimo, mas não erudito, que Thomas Mann possui da obra de Goethe, essas páginas dão fundamento e legitimidade às convicções que animam o autor. É Mann que se expressa completamente quando faz Goethe dizer a propósito daqueles que desconfiam de seu germanismo: "Não quero me reconciliar com eles. Eles não gostam de mim - perfeito, também não gosto deles, estamos quites. Tenho o meu próprio germanismo, o diabo que os leve, eles e o filistinismo, como eles assim chamam. Crêem que são a Alemanha - a Alemanha sou eu, e se seu corpo e seus bens tivessem de desaparecer, ela se perpetuaria em mim" (Mann, 1945, p.231).

Nas Meditações, Mann fazia novamente sua - sem, no entanto, nomeá-la - a definição fichtiana do alemanismo como universalidade. Essa definição, retomada por Ferdinand Lassalle, ${ }^{41}$ repousa na etimologia (anacrônica) do substantivo: Alleman = all-man, todo homem. "A nação alemã - como se pode ler-generalizou-se e depurou-se para se tornar um povo universal no qual toda a humanidade começa a reconhecer seu mestre e seu educador. Sim, nós somos, nós fomos, nós permanecemos os educadores, os filósofos, os teósofos, os professores de religião de toda a Europa e do mundo inteiro ... Nós somos, nós permanecemos um povo

40 Carta a Heinrich Mann, de 3 de março de 1940.

41 Cf. Dayan-Herzbrun, 1990, p.77ss. 
cidadão do mundo, um povo integrado à história universal ... e por este motivo, não podemos ser um povo estupidamente orgulhoso, bestialmente gregário" (Mann, 1975, p.209). Thomas Mann vai mostrar em seguida que a universalidade não existe sem humanismo, ${ }^{42}$ e ele faz com que Goethe expresse uma preocupação com o social conjugada sem conflito com o individualismo; a universalidade não deve levar em conta a totalidade?: "A conciliação, a compensação, não são esses o meu objetivo e a minha especialidade? A adesão, a tolerância, a valorização de elementos que parecem se excluir, o equilíbrio, a harmonia? Somente a conjunção de forças diversas forma o mundo, cada uma tendo sua importância, cada uma merecendo ser desenvolvida, e cada uma permanecendo autônoma. Individualidade e sociedade, consciência e ingenuidade, romanesco e senso prático" (Mann, 1945, p.231). Essa conciliação culmina na associação de Marx e de Hölderlin, que representam dois pólos inseparáveis da cultura alemã (como declara Mann ao final de sua conferência sobre Goethe e Tolstói) que devem ser lidos e meditados.

Mas essa Alemanha universalista e humanista é, sobretudo, cosmopolita. Goethe, o "sem-pátria", é um cidadão do mundo. Esse cosmopolitismo está ligado, ao mesmo tempo, à humanidade - "ubiqüidade universal" (p.231) - e ao germanismo, os dois sendo inseparáveis, pois o cosmopolitismo sela o caráter eminentemente espiritual da Alemanha. Goethe, o Europeu, o homem das viagens relatadas em Lotte - viagens reais à França, à Boêmia, à Itália, que se alternam com viagens imaginárias ao Oriente, junto às "radiosas Plêiades do firmamento árabe" e do "repertório de literatura bíblica e oriental" (p.234-5) -, é o herói do cosmopolitismo. É a propósito disso que Thomas Mann relembra com vigor: "O nacional depende da natureza, e o cosmopolita, do espírito. A palavra "étnico" resume em bloco duas concepções que não se reúnem comumente, as de paganismo e de raça, subentendendo que o seu contrário, quer dizer, toda concepção supranacional e humana, é do domínio do cristianismo intelectual". ${ }^{43}$ Não é, portanto, o judaísmo - humanista, posto que internacional - que constitui uma religião étnica, mas o fascismo alemão, paganismo populista voltado ao culto de Wotan e forma bárbara do romantismo. ${ }^{44}$

Judaísmo internacional, germanismo cosmopolita: o encontro não é um fato casual. Em Lotte, a lembrança de um pogrom recente na cidade

42 "Goethe und Tolstoï", em Mann, 1982, p.212ss.

43 "Goethe und Tolstoil", op. cit., p.121-2.

44 Cf. "Goethe und Tolstoi”, op. cit., p.165. 
húngara de Eger serve de pretexto para uma longa exposição detalhada sobre os judeus: elogios pelas "aptidões genéricas deste povo singular, seu gosto pela música e suas disposições para a medicina", ${ }^{45}$ suas "qualidades humanas e suas convicções morais" 46 e sua contribuição à cultura alemã: "O judeu, mesmo médio, quando escrevia, empregava habitualmente um estilo mais puro e mais compacto que o alemão especificamente nacional". ${ }^{47}$ Goethe também assinala o espírito de burguês sério (no sentido positivo que ele e Mann dão a esse termo) dos judeus, e expressa sua incompreensão diante dos desencadeamentos de ódio de que são objeto os judeus. Mas ele insiste, sobretudo, nas afinidades dos dois povos, ambos "sal da terra": "Essa antipatia, reforçada pela estima, só era comparável a uma outra: à inspirada pelos alemães, cujo destino e situação no quadro interno e externo das nações apresentavam grandes afinidades com os primeiros". 48 Que pavor se ocorressem outros acontecimentos "de que a noite sangrenta da Idade Média não teria sido mais que a prefiguração em miniatura", e se os alemães se tornassem por sua vez vítimas! $!^{49}$ Mesmo se Mann antecipa aqui o que será a sua aflição quando constatar, ao término da guerra, que da Alemanha que havia ternamente amado não resta quase nada, ele procura, inicialmente, dar vida de novo ao velho preceito cristão: "Não faça a outro etc.", confiando sempre na eficácia mágica das palavras e do mito.

Os alemães foram o povo protestatório: contra o nazismo, Thomas Mann refaz o caminho do protesto. Da mesma forma que Lutero retornara à origem do cristianismo, ele volta às fontes do germanismo. Outros, e dentre os maiores, denunciaram ou testemunharam. Mann escreve para edificar um mundo. Em um dos artigos que a ele consagra, Lukács (1979, p.13) defende a idéia de que, diferentemente de Goethe, não há nenhuma perspectiva de futuro utópico em Mann. A despeito de sua adesão ao socialismo, ele permanece apenas "representativo, enquanto símbolo vivo, do que há de melhor na burguesia alemã". Podemos nos perguntar, contudo, se não há, em Mann, uma forma particular de utopia, que seria não do futuro, mas do passado, na qual importaria não somente propor modelos humanos e sociais, mas principalmente reconstruir o presente para

\footnotetext{
45 Mann, 1945, p.289

46 Ibidem.

47 Ibidem.

48 Ibidem.

49 Ibidem.
} 
que possa escapar ao horror e entregar seu controle ao que a humanidade tem de melhor.

DAYAN-HERZBRUN, S. Thomas Mann: a writer against Nazism. Trans/Form/Ação (São Paulo), v.20, p.63-76, 1997.

- ABSTRACT: Thomas Mann's attack, from 1922 onwards, against Nazism is exemplar in the sense that it was promoted by a writer committed to the defence of liberty and not by a militant. He underlines fiction and myth as ways of fighting against the charms of Nazism and proclaims the permanence of a cultural, cosmopolitan Germany, a source of a universality which is alien to all kinds of ethnic particularities. Goethe, someone he is identified with, is the prominent figure of this Germany.

- KEYWORDS: Republic of Weimar; nazism; cosmopolitism; German literature.

\section{Referências bibliográficas}

BETZ, A. Exit et engagement. Paris: Gallimard, 1991.

DAYAN-HERZBRUN, S. L'invention du parti ouvrier. Paris, 1979.

Par le jeu et par le sang. L'Homme et la Société, n.107/108, 1993.

DUMONT, L. L'individualisme apolitique dans les considérations de Thomas Mann. In: L'idéologie allemande. Paris, 1991.

ELIAS, N. La civilisations des moeurs. Paris, 1991. . Norbert Elias par lui même. Paris, 1991.

HABERMAS, J. L'espace public. Paris, 1978.

LUKÁCS, G. Thomas Mann. Paris, 1979.

MANN, K. Le tournant. cap. IX. Paris: Solin, 1984.

MANN, T. Appels aux allemands. Paris: Martin Flinker, 1984.

. Charlotte à Weimar. Paris, 1945.

. Considérations d'un apolitique. Paris, 1975.

. Culture et politique. In: . Les maîtres. Paris: Grasset, 1979. Les exigences du jour. Paris: Grasset, 1976.

- Goethes 's Laufbahn als Schriftsteller. Frankfurt: Fischer Verlag, 1982. Lettres (1889-1936). Paris: Gallimard, 1966.

. Noblesse de l'esprit. Paris, 1960.

MICHNIK, A. La deuxième révolution. Paris, 1990. 